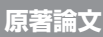

\section{アンサンブル予測雨量のダム洪水調節操作への 適用に関する研究}

$\begin{array}{lll}\text { 猪股 広典 1） 川崎 将生 1） } & \text { 後藤 祐輔 2) } \\ \text { 増田 有俊 2) } & \text { 荒木 千博 3) } & \text { 荒木 孝之 4) }\end{array}$

\author{
1）国土交通省 国土技術政策総合研究所 河川研究部 水循環研究室 \\ ( ( 305-0804 茨城県つくば市旭 1 番地) \\ 2）一般財団法人 日本気象協会 防災ソリューション事業部 水防ソリューション課 \\ (₹ 170-6055 東京都豊島区東池袋3-1-1 サンシャイン 6055 階) \\ 3）株式会社 建設技術研究所 大阪本社 河川部 \\ （ 541-0045 大阪府大阪市中央区道修町1-6-7） \\ 4）株式会社 建設技術研究所 東京本社 水システム部 \\ （广 103-8430 東京都中央区日本橋浜町 3-21-1 日本橋浜町Fタワー）
}

\begin{abstract}
本報告ではアンサンブル予測雨量を用いたダム洪水調節手法について検討を行った，具体的には，GSMを境界值 とした予測先行時間 84 時間のアンサンブル予測の計算を行い, 得られたアンサンブル予測雨量を用いて最適なダム 放流量を決定した，対象とした台風は 2011 年台風 6 号, 12 号, 15 号であり，この 3 洪水で洪水調節を実施したダムを 検討対象とした．台風6号, 15 号については 84 時間という長時間の予測であるにも関わらず満足なアンサンブル予測 雨量の精度が得られ，ダム洪水調節にとって非常に有意義な情報であることが分かった，それを用いて最適放流量 を決定してダム洪水調節を行った結果，本則操作と比較して下流のピーク流量を低下させることができた，その一 方で, 台風 12 号については満足なアンサンブル予測雨量の精度が得られず，それを用いた洪水調節操作は本則操作 と比較して下流の危険性を高める結果となった. ダム管理においては本則操作よりも下流の危険性を高める操作は 避けなければならないため, 実務への適用に向けては台風 12 号のような事例への対応手段が求められる.
\end{abstract}

キーワード : ダム洪水調節, アンサンブル予測

\section{I .はじめに}

気候変動に伴って世界的に豪雨が強大化する可能 性については，現在までにIPCCレポートやその他 の研究において多く指摘されており, 日本国内を対 象とした既往検討においても気候変動に伴って豪雨 の規模が増大する可能性が示唆されている（和田ら, 2004 ; 柏井ら, 2008). 豪雨の規模が増大化する可能 性が高い一方で，適応策として既存施設の能力をで きるだけ幅広く引き出すことがコストや早期効果発 現の面で極めて有効であり（社会資本整備審議会, $2008 ； 2015)$, 既設のダムにおいて洪水調節操作方 法を高度化することにより従来以上に洪水調節効果 を発揮させることが求められている.

既設ダムの治水機能向上の一つの方策として予測
雨量を活用した洪水調節が挙げられる。「予測雨量 を利用することでダムの洪水調節をより効果的に」 という発想自体はかなり以前より考えられており多 くの検討が実施されてきている（例えば三石ら， 2011a).しかし, ダムの洪水調節は予測雨量に対し て極めて高い精度を要求するため, 台風の降り終わ りにおける予測精度が高いことを利用した洪水後期 のオーバーカット等その利用は未だ限定的である (国土交通省中国地方整備局八田原ダム管理所, 2010 ；国土交通省東北地方整備局, 2011). 豪雨に対 する予測精度は日々向上しており, 今後とも精度向 上が進み, ダム洪水調節における適用も増加すると 見込まれるが，予測誤差が完全にゼロになるのは困 難である。そのため, 「予測雨量とは誤差を含んで 
いるが，それを用いることでダムの洪水調節効果を 高める可能性のあるデー夕」という認識を持ってそ の利用法を考えることが重要である(鳥居, 2012). その一例として, 過去の予測雨量について実績雨量 との比較から誤差の発生確率分布を設定し，その誤 差の発生確率分布を考慮（予測の幅を考慮すること に相当）して最適な放流量を決定する考え方が提案 されている（三石ら, 2011b).

一方で気象予測の分野では, 豪雨の予測で用いら れるメソ気象モデルのアンサンブル予測計算につい て研究が盛んに行われている（例えば吉野ら, 2011; Seko et al., 2011). アンサンブル予測とは，一つの初 期值による予測では気象の時間推移の評価が難しい という認識に基づき, 複数の初期值について予測計 算を行うことによって得られた予測の幅を評価する ものである (気象庁). 気象庁は1ケ月, 3个月といっ た長期予測においては既にアンサンブル予測を現業 化しており, 数日程度の短期アンサンブル予測につ いても試験運用が始まっている（永戸, 2013）.

このように, 気象予測の分野では予測の幅を評価す るアンサンブル予測が豪雨予測についても運用されつ つあり, ダム分野においては予測の幅を利用して最適 な放流量を決定する基本的な考え方が提案されはじめ たのが現状である.アンサンブル予測雨量の河川分野 における利用に関する研究では，国内外で精度評価や 流出計算への適用事例は挙げられるが（例えば牛山 ら, 2014 ; Yu et al., 2013 ; Cloke et al., 2009)，アンサン ブル予測雨量に基づいたダム洪水調節操作に関する検 討は未だ行われていない，本検討では過去の複数の出 水事例についてメソアンサンブル予測雨量（以下，本 報告においては断りがない限り「アンサンブル予測」 は「メソアンサンブル予測」を示すものとする.）の 計算を行い，その結果を基に（三石ら，2011b）で提案 されている予測雨量の誤差発生確率を考慮したダム洪 水調節手法に対して適用することで，現時点における 適用性および今後の課題について述べる。

\section{II．シミュレーション実施内容}

\section{1. 検討対象流域・ダム, 対象洪水}

アンサンブル予測雨量を活用したダム洪水調節の 検討対象流域として, 平成 23 年に複数の台風により 洪水調節操作を実施した紀伊半島に位置する Aダム (流域面積約 $80 \mathrm{~km}^{2}$ ) を含むB川流域（流域面積約 $450 \mathrm{~km}^{2}$, 治水基準地点: C地点（A ダムから約 60 $\mathrm{km}$ 下流））を対象とした。検討対象とする台風拉よ びその検討対象期間は以下の通りである.

台風6 号：2011年7月 15 日9時〜 7月 20 日 15 時 台風 12 号：2011年 8 月 29 日 9時〜 9 月 4 日 15 時 台風 15 号：2011年 9 月 16 日 9 時 $~ 9$ 月 21 日 21 時

\section{2. アンサンブル予測雨量の計算}

\section{1. 実施したアンサンブル予測計算の概要}

アンサンブル予測雨量は, 気象庁 GSMの 84 時間 予測を初期值・境界值として, WRF（Weather Research and Forecasting Model）により計算した。 各台風につ いて上述の対象期間について, GSM（領域：日本域, 空間解像度：20 km, 予測更新間隔：6時間毎 $(03$, 09, 15, $21 \mathrm{JST}$ ), 予測先行時間 : 84時間, 時間解像 度：毎時）の予測が更新される毎にその予測值を初 期值・境界值として 84 時間先までの計算を行う。予 測に用いる初期值についてはその時点よりも6時間 前に行った予測計算結果㧍よび観測值を基に次項に 概要を記すHybrid ETKF-3DVAR法 (Wang et al., 2008a；2008b）によるデー夕同化を行った，計算領 域については図ー1に示し, 空間解像度は親領域に おいて $15 \mathrm{~km}$ とした。 子領域は $\mathrm{A}$ ダムが領域中央付 近に位置するように設定し, 空間解像度は $5 \mathrm{~km}$ とし た. 鉛直層の数は親領域, 子領域共に50層とした. WRFによるシミュレーションにおいて採用した物理 過程およびデー夕同化に用いた観測デー夕一覧を

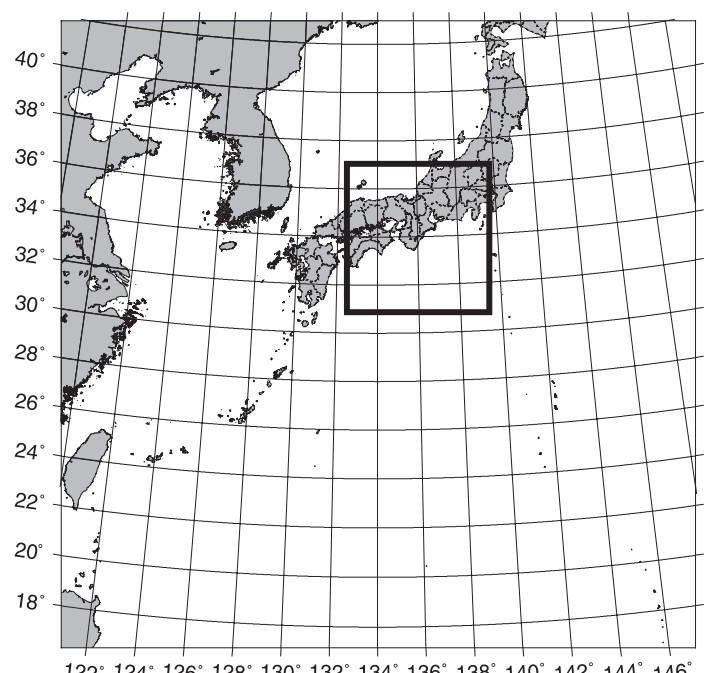

図-1 計算領域（全体が親領域, 太枠内が子領域）

Fig. 1 Simulation domain: the whole area is the outer domain; the area surrounded by the thick solid line is the inner domain. 
表ー1および表一2に示す。ここでアンサンブルメン バー数は計算機環境および計算所要時間を考慮して 20 とした。しかし，HybridETKF-3DVAR法を用いた既 往研究ではアメリカに上陸した2つのハリケーンの予 測進路シミュレーションに32メンバーを用いており (Wang, 2011)，アンサンブルメンバー数の違いが予測 結果に与える影響については今後の検討事項である.

\subsection{Hybrid ETKF-3DVAR法の概要}

シミュレーションにより求めた状態（例えば風速） の推定值および観測值を用いてその時点の状態の最 も確からしい值（以降，解析值と呼ぶ）を推定する 行為をデータ同化と呼び, 3 次元変分法（以下, 3DVAR）はデー夕同化の代表的な一手法である。 3DVARでは，任意の值から推定值および観測值それ ぞれまでの距離の和を表す評価関数を導入し，この 関数を最小とする值を反復計算により探索し，求 まった值を解析值とする方法である。詳細は文献を 参考にして頂きたいが（例えば碓水ら, 2009）, 解析 值を求める過程においてシミュレーションの誤差情 報が必要となる.3DVARにおいて誤差情報はシミュ レーションの統計的な誤差分散で与えられ, 台風, 前線といったその時々の気象状況の違いや時間変化 を考慮せずに常に一定とする。しかし，その時々の 気象状況を考慮した誤差情報を組み入れることで解 析值の精度が向上することが示唆されている（Wang

\section{表-1 採用した物理過程}

Table 1 Applied physical process for WRF simulation.

\begin{tabular}{l|l}
\hline \multicolumn{1}{c|}{ 物理過程 } & \multicolumn{1}{c}{ スキーム } \\
\hline 雲物理過程（親領域） & WRF Single-Moment 5-class scheme \\
\hline 雲物理過程（子領域） & WRF Single-Moment 6-class scheme \\
\hline 積雲パラメタリゼーション & Kain-Fritsch scheme \\
\hline 長波放射 & Rapid Radiative Transfer Model \\
\hline 短波放射 & Dudhia scheme \\
\hline 地表面 & Noah Land Surface Model \\
\hline 境界層 & Yonsei University scheme \\
\hline 接地層 & Monin-Obukhov \\
\hline
\end{tabular}

表ー2 データ同化に用いた観測データ一覧

Table 1 List of observed data used for the data assimilation.

\begin{tabular}{|c|c|c|}
\hline 種別 & 要素 & 入手先 \\
\hline 気象観測衛星（AMSU-A, B) & 気温, 水蒸気 & \multirow{4}{*}{$\begin{array}{l}\text { NCAR Research } \\
\text { Data Archive }\end{array}$} \\
\hline 衛星大気追跡風 & 風 & \\
\hline $\begin{array}{l}\text { 高層実況, 海上実況, 飛行 } \\
\text { 場, 地上実況 }\end{array}$ & \begin{tabular}{|l} 
気温, 風, 水 \\
蒸気, 氖
\end{tabular} & \\
\hline 航空機実況 & 気温, 風 & \\
\hline ドップラーレーダ & $\begin{array}{l}\text { 風, 反射強度 } \\
\text { 雨水) }\end{array}$ & $\begin{array}{l}\text { 気象業務支援セン } \\
\text { 多ー }\end{array}$ \\
\hline
\end{tabular}

et al., 2008a).

Hybrid ETKF-3DVAR 法は, 3DVAR を基本としつつ も初期值が異なる複数のアンサンブルメンバーを用 いて予測シミュレーションを実施し, 予測結果に関 する分散を統計的な誤差分散と併用することで解析 值の精度向上を図る手法である. Hybrid ETKF-3DVAR 法の処理の過程を図一2に示す。最初に各アンサン ブルメンバーについて予測シミュレーションを実施 し (1)), 状態のアンサンブル平均值（2)）および 各アンサンブルメンバーについて予測された状態の 推定值とアンサンブル平均值との偏差を算出する (3)). 各アンサンブルメンバーについて求められた 偏差から分散を算出し (4)), これとアンサンブル 平均值, 観測值および統計的な誤差分散を入力とし て3DVARにより解析值を求める (5))。ここで, (4) で求めた分散はその時々のアンサンブルシミュレー ションの結果に基づく值であるため時間変化する. また，(3)で求めた各アンサンブルメンバーの偏差に ついては, 推定值の偏差について観測值を用いて データ同化する手法の一種であるアンサンブル変換 カルマンフィルタ (ETKF) (Bishop et al., 2001) に より更新する（6)．次に, 3DVARによって求まった 解析值にETKFにより更新された各アンサンブルメ ンバーに関する偏差を加えることで, 各アンサンブ ルメンバーの状態量が更新される（7)），その更新 された状態量を初期值として次の予測計算を実行す る(8)）．以降は(1)〜8)を繰り返す.

\section{3. アンサンブル予測雨量を用いたダム洪水調節 手法}

2.の手法で計算されるアンサンブル予測雨量を用

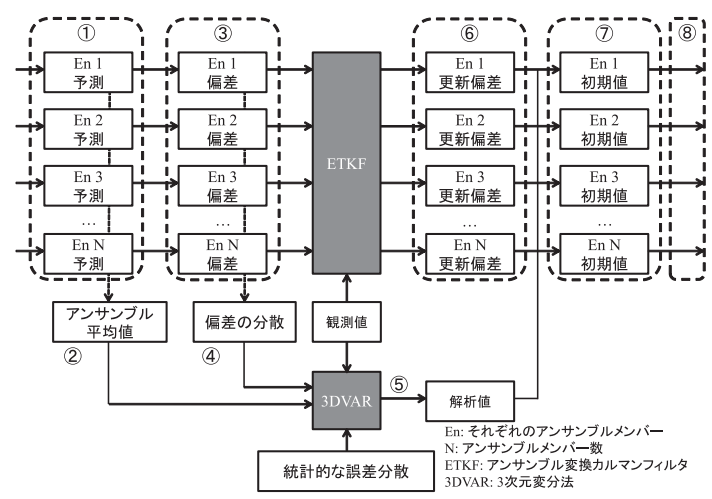

図－2 Hybrid ETKF-3DVAR法によるデータ同化処理過程

Fig. 2 Data assimilation process by Hybrid ETKF-3DVAR. 
いて，(三石ら，2011b）を参考にダム最適放流量を 以下の通り決定した。

1）洪水調節開始流量（本検討では $200 \mathrm{~m}^{3} / \mathrm{s}$ ) から計 画最大放流量（本検討では $350 \mathrm{~m}^{3} / \mathrm{s}$ ）の間を 200 , $240,280,320,350 \mathrm{~m}^{3} / \mathrm{s}$ に分けた 5 通りの一定量放 流方式による操作ケースを予如設定する. 以下, $200 \mathrm{~m}^{3} / \mathrm{s}$ の一定量放流方式を「操作ケース $1 」, 240$ $\mathrm{m}^{3} / \mathrm{s}$ の一定量放流方式を「操作ケース $2 」 \cdots, 350$ $\mathrm{m}^{3} / \mathrm{s}$ の一定量放流方式を「操作ケース $5 」$ のよう に記す。

2）GSMの予測が更新されるタイミングで, 2.で示し た予測先行時間 84 時間のアンサンブル予測雨量 の計算を行う，得られた各アンサンブルメンバー の予測雨量の結果をここでは $\mathrm{m} 01, \mathrm{~m} 02, \cdots$, $\mathrm{m} 20$ とする.

3）得られたアンサンブル予測雨量のメンバー1 (m01) についてダム流域を含めた流域全体で流出計算 を行う。

4）3）においてダム流域について得られる予測流入 量に対し, 操作ケース $1\left(200 \mathrm{~m}^{3} / \mathrm{s}\right.$ の一定量放流方 式）で操作したときの下流基準地点 (C地点) の ピーク流量を計算する。ここでは求められたピー ク流量を，アンサンブルメンバー1（m01）の流出 に対して操作ケース1で調節した結果という意味 で $\mathrm{Q}_{\mathrm{p} 1 \_\mathrm{m} 01}$ と表記することとする。

5）3）と4）と同様の計算により，操作ケース 1 に ついてその他のアンサンブルメンバー（m02, $\mathrm{m} 03, \ldots, \mathrm{m} 20$ ）に対する下流基準地点ピーク流量 $\left(\mathrm{Q}_{\mathrm{p} 1 \_\mathrm{m} 02}, \mathrm{Q}_{\mathrm{p} 1 \_\mathrm{m} 03}, \ldots, \mathrm{Q}_{\mathrm{p} 1 \_\mathrm{m} 20}\right)$ を算出する.

6）各アンサンブルメンバーの発生確率は等しいも のとし，4）拈よび5）で計算したアンサンブルメ ンバー毎の下流基準地点ピーク流量を算術平均 することで, 操作ケース 1 で操作した時の下流基 準地点ピーク流量期待值を得る $\left(\mathrm{Q}_{\mathrm{p} 1}\right)$.

$Q_{p 1}=\left(\sum_{e=1}^{20} Q_{\mathrm{p} 1 \_\mathrm{me}}\right) / 20$

7）3）～6）の計算を1）で設定した残り4つの操作 ケースについても同様に行うことで, 操作ケー ス毎の下流基準地点ピーク流量期待值 $\left(\mathrm{Q}_{\mathrm{p} 2}, \mathrm{Q}_{\mathrm{p} 3}\right.$, $\mathrm{Q}_{\mathrm{p} 4}, \mathrm{Q}_{\mathrm{p} 5}$ ) を計算する.

8）7）までの計算で全操作ケースについて得られた 下流基準地点ピーク流量期待值を比較し，下流 基準地点ピーク流量期待值を最小にする操作 ケースをその時点に㧍ける最適操作として次の
GSMの予測更新までその放流量で操作する。

9）GSMの予測が更新される度に2）～8）の計算・ 操作を行うことで最適操作を決定する.

なお，上記計算においてダム貯水位がただし書き 操作開始水位を超過した場合は, ただし書き操作実 施要領に基づく既定の操作に移行するものとした.

上記計算をアンサンブル計算の境界值である GSM の予測が更新されるたびに行い，洪水が終了するま で実施した。 上記操作は, 確率的に最も発生する可 能性が高い予測に対して最適操作（洪水調節容量を 極力多く使用して下流河川の流量を低減させる.） を実施することに相当する.

なお，上記3）の流出計算においては土研分布モ デル（鈴木ら, 1996 ; 猪股ら, 2007）を用いた. 土研 分布モデルのパラメータは, 対象 3 洪水の実績雨量, Aダム流入量およびC地点の実績流量を用いて SCEUA法（Duan et al., 1992）により最適化を行った.

\section{III. 計算結果}

\section{1. 台風6号の結果}

\section{1. アンサンブル予測雨量}

最初に台風6号の結果について示す。図一3は, 実績のダム流入量が洪水調節開始流量に到達する 約 1 日前の時点（7月18日9時）を初期時刻として 予測した結果である。図一3の左図に示す時系列の 予測結果では, 降り始めの直後に発生する $40 \mathrm{~mm} /$ $\mathrm{hr}$ 程度の雨をアンサンブル予測雨量では予測でき ていない。また, 7月20日の未明以降は雨がほとん ど観測されていないにも関わらず, アンサンブル 予測ではほぼ全てのメンバーが 5 ～ $30 \mathrm{~mm} / \mathrm{hr}$ 程度 の雨を予測しており, 過大評価している。要因に ついては次章で考察する。しかし, ダムの洪水調 節において最も重要である総雨量の観点では, ア ンサンブル平均（黒太線）に着目すると高い精度 が得られていることが分かる（図一3，右図）。ま た, ダム流入量が洪水調節開始流量に到達する 1 日 前の時点の予測であるにも係わらず, 雨の降り終 わりまでほぼ見通すことができていることもダム の洪水調節にとっては有意義な情報である。図一3 には現在運用されている長時間の予測情報として MSM33時間予測（領域：日本域, 空間解像度 : 5 $\mathrm{km}$, 予測先行時間および予測更新時間：15 時間 (0, 6, 12, 18 UTC） および33時間 ( $3,9,15,21$ UTC), 時間解像度：毎時 ※2011年時点での仕様）の結 
果を併せて図示しているが，MSMでは一山目の終 わりまでしか見通すことができておらず，今回の 検討で計算したアンサンブル予測雨量の有効性が 確認できる。また，図一4は初期時刻別のアンサン ブル平均雨量の時系列（左図）および積算雨量（右 図）である。な扮右図に示古積算雨量については, 予測初期時刻までの観測の積算雨量に予測雨量を 足して表示している。今回の検討でアンサンブル 予測計算は 1 日 4 回分 $(03,09,15,21 \mathrm{JST})$ の初期 時刻について実施したが，ここでは図を簡明にす るため 1 日 2 回分（09, 15 JST）の初期時刻の予測 結果を図に示し，また降雨が降り始める約 1 日前か ら最後の降雨のピークが生じた7月19日21時を初 期時刻とする予測結果までを図に示した。図一4左 図に示す時系列では，初期時刻毎に予測結果にあ る程度のばらつきがある。また，図一4右図に示す 積算雨量では最大で約 $40 \%$ 程度過大評価する初期
時刻が存在するが, 概ね良好な精度の予測結果が 得られた。また, 予測初期時刻毎に過大評価と過 小評価が入れ替わるような不安定な予測ではなく, いずれの初期時刻についても一貫して過大評価傾 向であった.

\section{2. 洪水調節計算}

次に，台風6号についてII.3.で述べた手法により ダム洪水調節操作を行った結果を図一 5 に示す。こ の結果, 本則操作 (最大放流量 $350 \mathrm{~m}^{3} / \mathrm{s}$ の一定量放 流方式）の場合は洪水時の最大放流量は $350 \mathrm{~m}^{3} / \mathrm{s}$ で あり, 貯水量最大時において洪水調節容量の $18 \%$ を使用した。 それに対しアンサンブル予測雨量に基 づく計算結果では, 最大放流量は7月 19 日 9 時〜 15 時にかけての $240 \mathrm{~m}^{3} / \mathrm{s}$ であり, その後は $200 \mathrm{~m}^{3} / \mathrm{s}$ ま で放流量を下げる結果となった。貯水容量の使用率 については, 貯水量最大時において洪水調節容量の
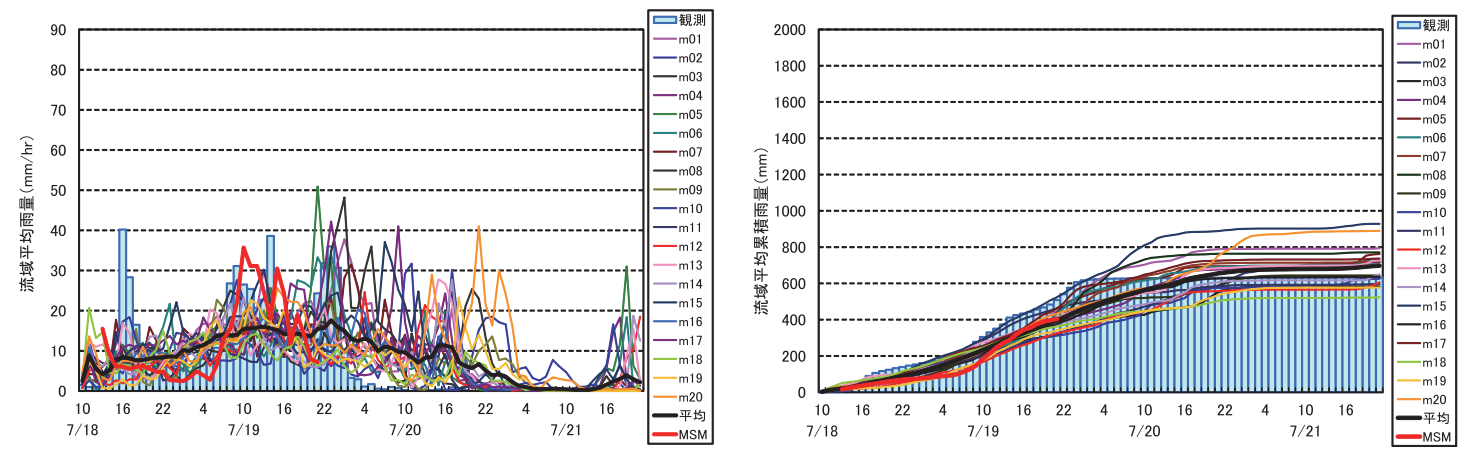

図－37月18日9時のGSMを初期值としたAダム流域平均雨量の84時間アンサンブル予測結果（左：84時間の時 系列, 右 : 積算雨量)

Fig. 3 84-hr lead time ensemble forecast of areal rainfall in A dam watershed. Initial date and time: GSM at 09 JST 18 July 2011. Left panel: 84-hr time series. Right panel: cumulative rainfall.
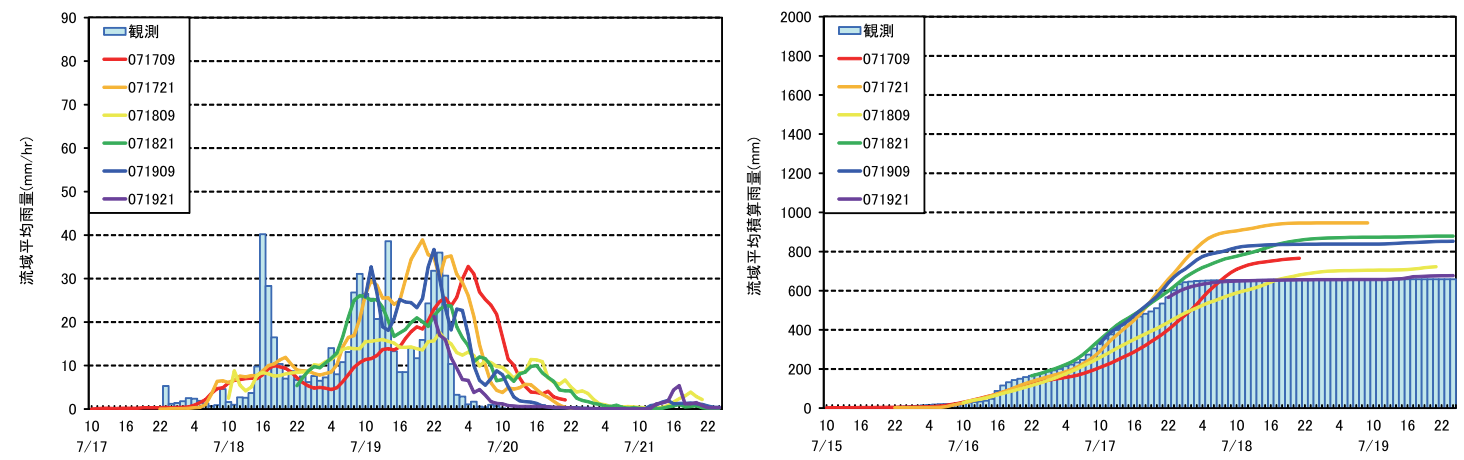

図-4 初期時刻別のアンサンブル平均值（台風6号, 左：84時間の時系列，右：積算雨量）

Fig. 4 Ensemble average of areal rainfall in A dam watershed for each initial time. Typhoon 6: left panel, 84-hr time series; right panel, cumulative rainfall. 


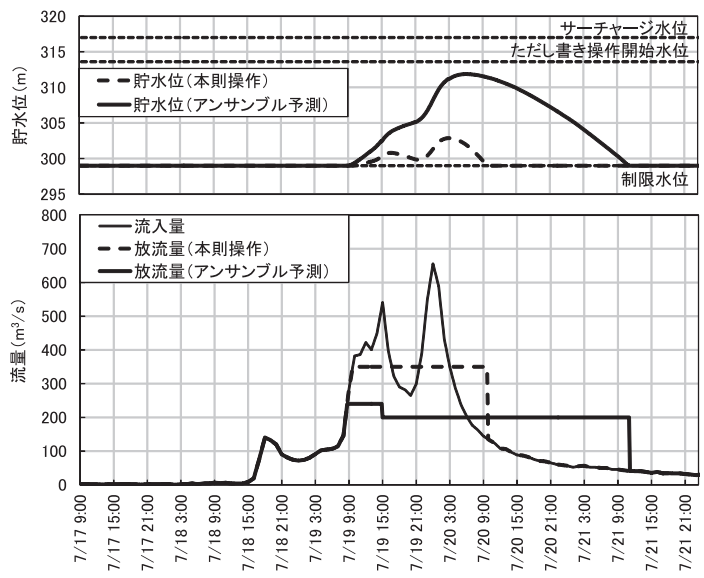

図 -5 台風 6 号時の $\mathrm{A}$ ダムの流入量, 放流量および貯 水位の時系列

Fig. 5 Time series of inflow, outflow, and water level at A dam: Typhoon 6.

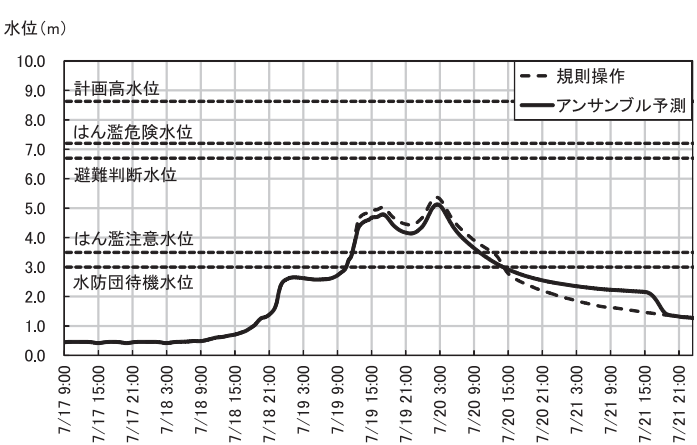

図 -6 台風 6 号時の $\mathrm{C}$ 地点の水位の時系列

Fig. 6 Time series of water level at $\mathrm{C}$ point: Typhoon 6 .

$67 \%$ を使用し, 本則操作よりも多い容量を使用して いる. 図一6に下流基準地点である $\mathrm{C}$ 地点の水位の 時系列を示す。ピーク水位については, 一つ目の ピーク，二つ目のピークともにアンサンブル予測雨 量に基づく操作は本則操作と比較して約 $20 \mathrm{~cm}$ 低く することができ，本則操作と比較して効果的な洪水 調節を行うことができた。

\section{2. 台風 12 号の結果}

\section{1. アンサンブル予測雨量}

次に台風 12 号の結果について示す。図一7は，実 績の夕゙ム流入量が洪水調節開始流量に到達した時間 の約 1 日前の時点（9月1日9時）を初期時刻として 予測した結果である。図一7の左図を見ると，実績 の降雨は大きく二つのピークが観測されている。 そ れに対してアンサンブル予測は，一つ目のピークま
ではタイミング，雨量共に概ね精度良く予測できて いるが，全てのアンサンブルメンバーが一つ目の ピークを過ぎたところで雨が降り止むと予測して二 つ目のピークを予測できない結果となった。図ー7 の右図に示される積算雨量についても，二つ目の ピークを予測できなかったためアンサンブル平均は 実績積算雨量の半分程度の予測にとどまり, アンサ ンブルメンバーの中で最も大きい積算雨量を示す予 測でも実績積算雨量よりも小さい予測となった。要 因については次章で考察する。また，図一8は初期 時刻別のアンサンブル平均雨量の時系列（左図）お よび積算雨量（右図）である。図一8の左図に示す 時系列では，やはりいずれの初期時刻の予測につい ても二つ目のピークを予測することができていない ことが分かる，特に，二つ目のピークが降る直前で ある9月3日21時の予測においても二つ目のピーク を見逃す予測となっている。図一8右図に示す積算 雨量ではいずれの初期時刻についても一貫して過小 評価傾向であり，イベント後半の予測である9月 3 日9時や9月3日21時の予測においても二つ目の ピークを相当程度過小評価しているために積算雨量 としてもかなりの過小評価となった.

\section{2. 洪水調節計算}

次に，台風12号についてII.3.で述べた手法によ りダム洪水調節操作を行った結果を図一9に示す。 本則操作の場合は 9 月 3 日 20 時頃にただし書き操作 に入り，放流量の最大值は9月 4 日9時頃の約 580 $\mathrm{m}^{3} / \mathrm{s}$ であった。 また，洪水調節容量は最大時で $81 \%$ を使用している。 それに対しアンサンブル予測雨量 に基づく計算結果では，上述した通り二つ目のピー クをアンサンブル予測が見逃しているために，一つ 目のピークに対して洪水調節容量を使い切る操作を 行っている，実際には，予測できなかった二つ目の ピークが存在したため, 二つ目のピークを迎える頃 には本則操作と同様に既にただし書き操作に入って おり，放流量が約 $580 \mathrm{~m}^{3} / \mathrm{s}$ まで増加した。図一10に 下流基準地点である $\mathrm{C}$ 地点の水位の時系列を示す. 一つ目のピークは本則操作よりも約 $10 \mathrm{~cm}$ 低減させ ることができたが，二つ目のピークはただし書き操 作に入った結果として本則操作の場合と比較してほ ぼ同じ水位となった。しかし，アンサンブル予測雨 量に基づく操作では本則操作と比較してかなり早い タイミングでただし書き操作に移行（9月3日13時 頃）してしまった点が大きな問題である。 

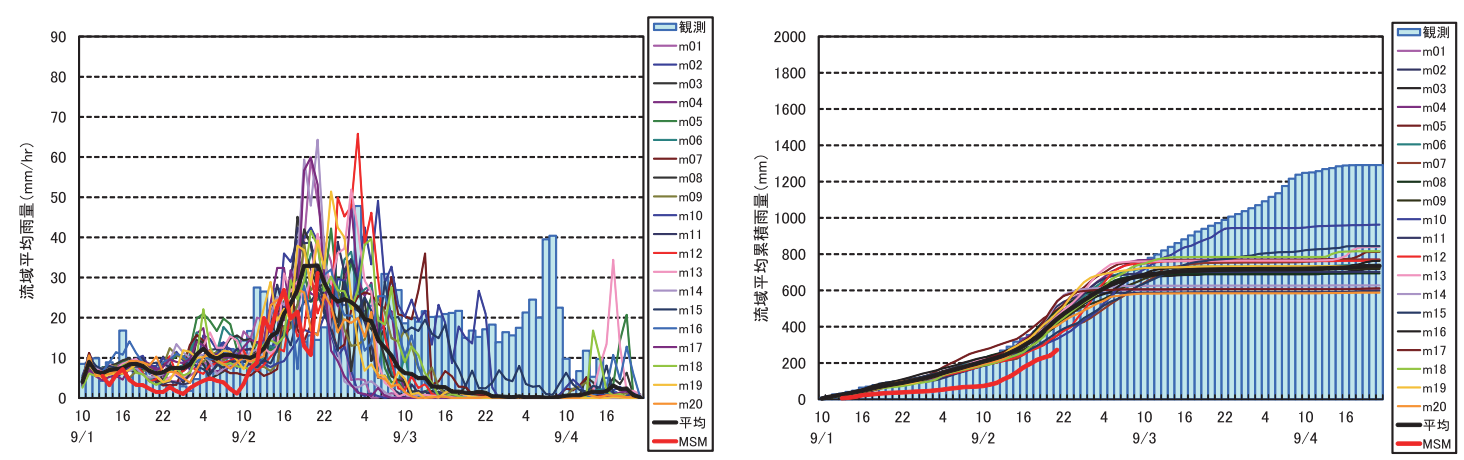

図-7 9月1日9時の GSMを初期值としたAダム流域平均雨量の84時間アンサンブル予測結果（左：84時間の時系 列, 右 : 積算雨量)

Fig. 7 84-hr lead time ensemble forecast of areal rainfall in A dam watershed. Initial date and time: GSM at 09 JST 1 Sep. 2011. Left panel: 84-hr time series. Right panel: cumulative rainfall.
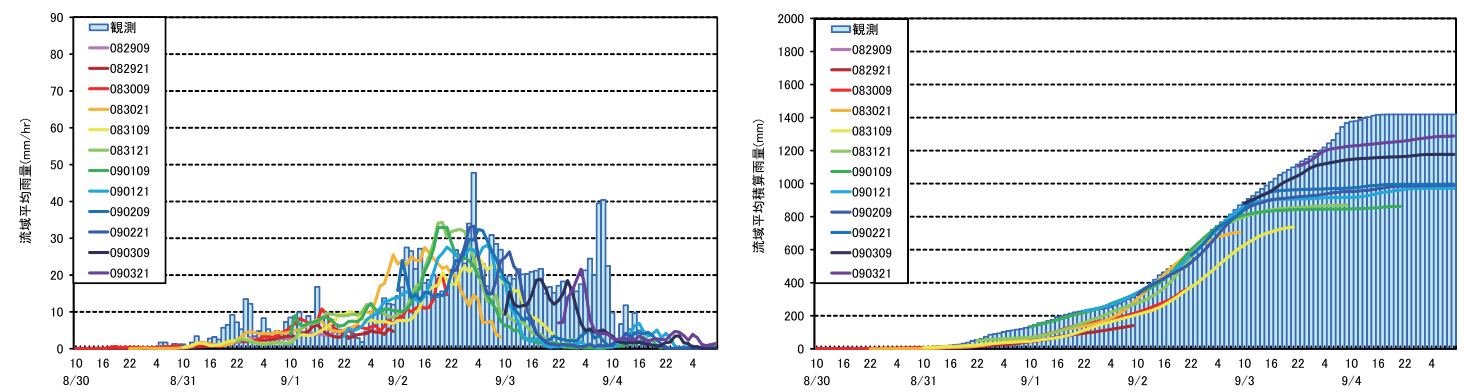

図 -8 初期時刻別のアンサンブル平均值（台風 12 号, 左 : 84 時間の時系列, 右 : 積算雨量)

Fig. 8 Ensemble average of areal rainfall in A dam watershed for each initial time. Typhoon 12: left panel, 84-hr time series; right panel, cumulative rainfall.

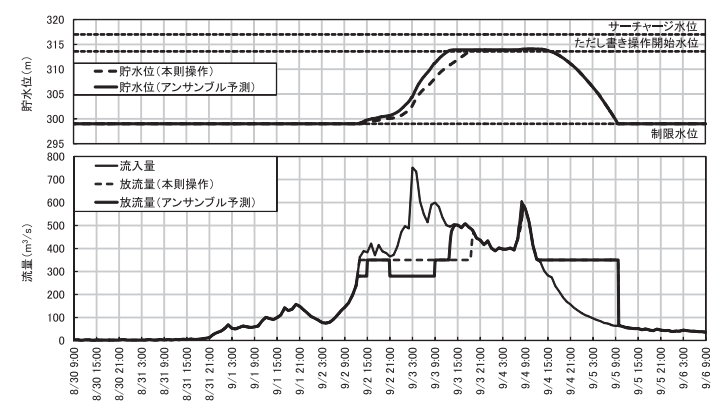

四 -9 台風 12 号時の A ダム流入量, 放流量および貯水 位の時系列

Fig. 9 Time series of inflow, outflow, and water level at A dam: Typhoon 12 .

\section{3. 台風 15 号の結果}

\section{1. アンサンブル予測雨量}

次に台風 15 号の計算結果について示す. 図一11 は，実績のダム流入量が洪水調節開始流量に到達し た時間の約 1 日前の時点（9月20日3時）を初期時 刻として予測した結果である。図一11の左図による

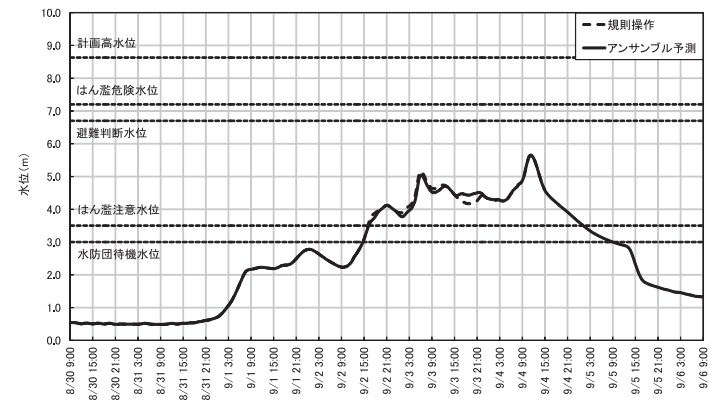

図 - 10 台風 12 号時の $\mathrm{C}$ 地点の水位の時系列

Fig. 10 Time series of water level at C point: Typhoon 12.

と, 台風 15 号は 2 日程度で終了した洪水であったた めGSM84 時間予測を初期值・境界值として行った 予測計算は降雨の降り始めから終わりまでを見通す ことができている。 また，アンサンブル平均は降雨 のピークを量, タイミング共に正確に予測できてお り, 図一11の右図に示される積算雨量の值について もアンサンブル平均は観測值と相違ない結果となっ 

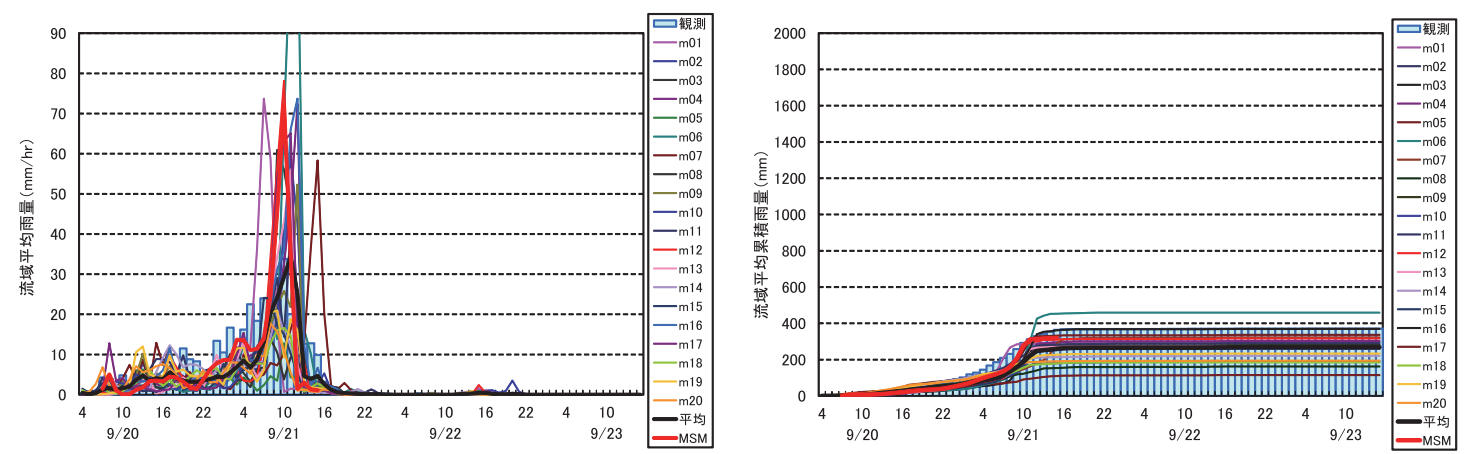

図-119月20日3時のGSMを初期值としたAダム流域平均雨量の 84 時間アンサンブル予測結果（左：84時間の時 系列, 右 : 積算雨量)

Fig. 11 84-hr lead time ensemble forecast of areal rainfall in A dam watershed. Initial date and time: GSM at 03 JST 20 Sep. 2011. Left panel, 84-hr time series. Right panel, cumulative rainfall.
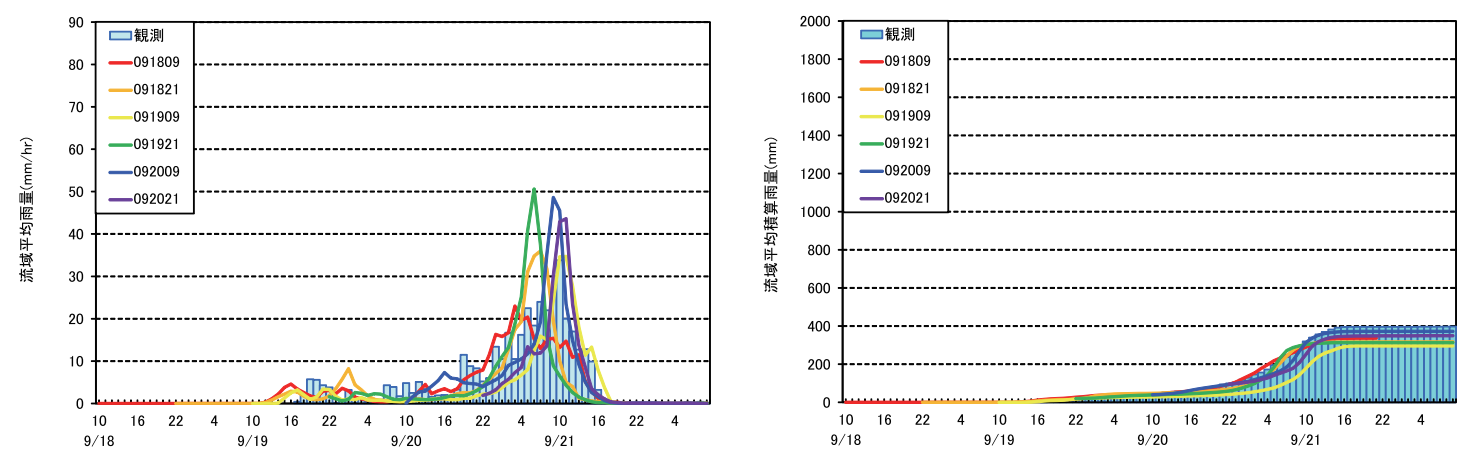

図 - 12 初期時刻別のアンサンブル平均值（台風 15 号, 左 : 84 時間の時系列, 右：積算雨量）

Fig. 12 Ensemble average of areal rainfall in A dam watershed for each initial time. Typhoon 15: left panel, 84-hr time series; right panel: cumulative rainfall.

た。また，図一12は初期時刻毎のアンサンブル平均 雨量の時系列（左図）および積算雨量（右図）であ る。図-12の左図に示す時系列では，初期時刻毎に 予測結果に大きな差が見られず台風 6 号および 12 号 の予測と比較すると安定した予測が行われた。図一 12右図に示す積算雨量ではやや過小評価する初期時 刻が存在するが，いずれの初期時刻についても安定 して良好な予測が行われた。

\section{2. 洪水調節計算}

次に, 台風 15 号についてII.3. で述べた手法によ りダム洪水調節操作を行った結果を図ー13に示す. この結果, 本則操作の場合は洪水時の最大放流量は $350 \mathrm{~m}^{3} / \mathrm{s}$ となり, 貯水量最大時において洪水調節容 量の $8 \%$ を使用した。 それに対しアンサンブル予測 雨量に基づく計算結果では，最大放流量 $200 \mathrm{~m}^{3} / \mathrm{s}$ の 一定量放流となり，最大時において洪水調節容量の
$30 \%$ を使用した。また，図一14に下流基準地点で ある C地点の水位の時系列を示す。ピーク水位につ いては, アンサンブル予測雨量に基づく操作は本則 操作と比較して約 $20 \mathrm{~cm}$ 低くすることができ, 本則操 作と比較して効果的な洪水調節を行うことができた.

\section{IV. 考察}

前章に記した通りアンサンブル予測雨量の精度は イベント毎に異なっており，II.3.で述べたアンサン ブル予測雨量を用いたダム洪水調節手法が本則操作 と比較して効果があるか否かはアンサンブル予測雨 量の精度に強く依存することが分かる。ここでは, アンサンブル予測およびその初期值・境界值として 用いたGSMで予測されている台風進路と気象庁の ベストトラックデータから得られる実績の台風経路 に着目してアンサンブル予測雨量の精度との関係に 


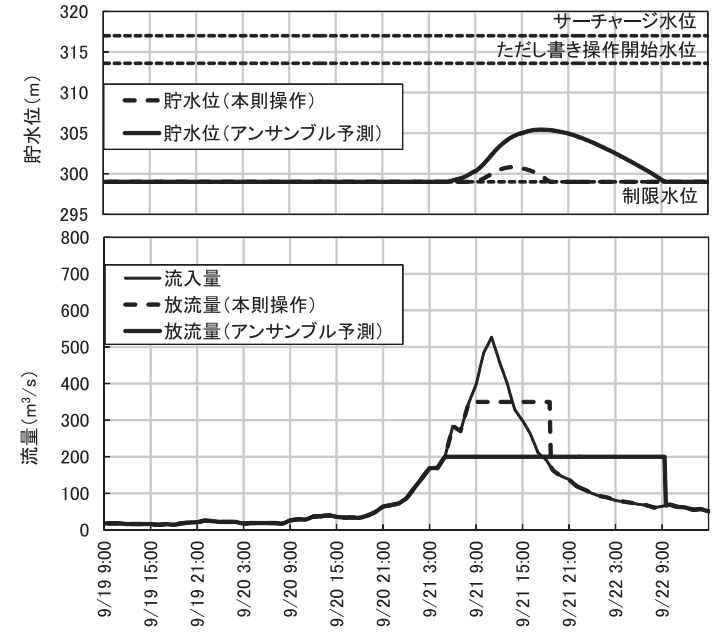

図-13 台風 15 号時の $\mathrm{A}$ ダムの流入量, 放流量および 貯水位の時系列

Fig. 13 Time series of inflow, outflow, and water level at A dam: Typhoon 15.

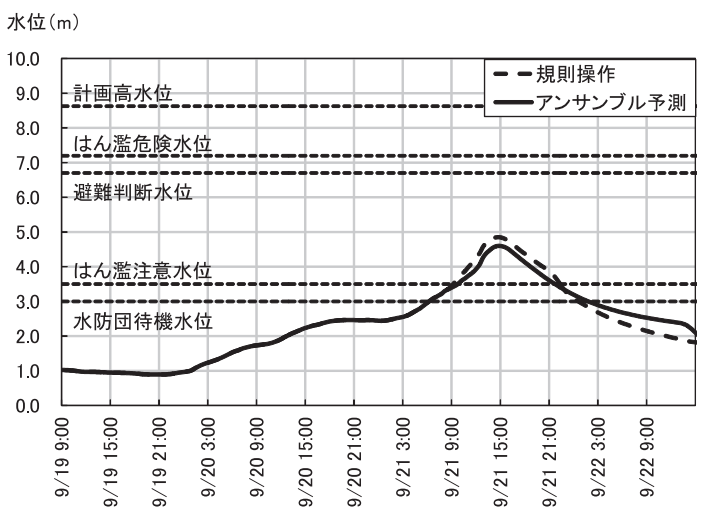

図-14 台風 15 号時の C地点の水位の時系列

Fig. 14 Time series of water level at $\mathrm{C}$ point: Typhoon 15.

ついて述べた後，実務への適用に向けた課題につい て述べる。なお以降においてアンサンブル予測およ びGSMの台風位置は地上気圧が最も低い位置とし ている。またベストトラックデータは, 衛星画像や レーダデータをはじめとしたリアルタイムで取得さ れる情報を基に解析された台風諸元（台風の中心位 置, 中心気圧, 最大風速など）に，事後に入手され る情報を加えて改めて解析を行って確定された台風 諸元データである.

\section{1. アンサンブル予測雨量の精度と台風進路の関係}

ここでは，前章とは異なり台風 15 号, 6 号, 12 号の 順序で説明する。
台風 15 号において, 流入量が洪水調節開始流量に 到達する約 1 日前である 9 月 20 日 3 時を初期時刻と した予測（図一11と同じ初期時刻）では，図一15 に示すとおりアンサンブル予測の境界条件として用 いたGSMは, 24 時間先予測および36時間先予測にお いてそれぞれ約 $130 \mathrm{~km}$, 約 $180 \mathrm{~km}$ ほどベストトラッ クより離れているが, その一方でアンサンブル予測 では進路・進行速度共にリードタイムの長さに関わ らず概ねべストトラックに近いことが分かる。その 結果として図ー11に示したようにアンサンブル予測 雨量の精度は全般的にかなり高い予測精度を示した と考えられる.

次に台風6号の場合, 図ー16に示すようにベスト トラックでは台風は四国に向かって南から北上して 室戸岬付近を通過した後に紀伊半島を通過, その後 南東に向けて進んだ。図ー16に示す7月 18 日9時を 初期時刻とした子測（図一3 と同じ初期時刻）では, 24 時間先まではGSMおよびアンサンブル予測共に ベストトラックに近い予測を行っているものの, 36 時間先から長い予測時間になるとGSMおよびアン サンブル予測共にベストトラックとは離れた予測を 行っており，両者は約 $110 \mathrm{~km}$ 離れている。また 36 時間先以降においては, アンサンブル予測はべスト トラックよりも北側に大回りする予測を行ってい る。この大回りする予測が原因となってアンサンブ ルで予測された台風は実際よりも紀伊半島にある $\mathrm{A}$ ダム付近への接近および通過のタイミングが遅く なった。これにより, 図一3の左図に示したように 降雨の前半部分で過小評価, 後半部分で過大評価と なったと考えられる。

次に台風 12 号の場合, 台風本体が紀伊半島に近づ いてきた 9 月 1 日9時を初期時刻（図一7と同じ初期 時刻）とした予測では，図一17に示すとおり48時 間後の予測においては多くのアンサンブルメンバー で台風は中国地方から日本海側に抜けると予測され ているのに対し，ベストトラックでは48時間後にお いても四国の室戸岬近辺に位置している。さらに， 72 時間後の予測では全てのアンサンブルメンバーが 日本海に抜けて時間が経過しているのに対し, ベス トトラックでは中国地方をわずかに北に抜けた程度 である。このことから実績の台風はアンサンブル予 測よりも長い時間をかけて四国地方から中国地方を 通過したものと考えられる。これにより実績の雨は Aダム流域において長時間降り続いたのに対し，ア ンサンブル予測は実績の雨よりも早く降り止み過小 
台風経路図 [2011年09月20日03時(JST)]

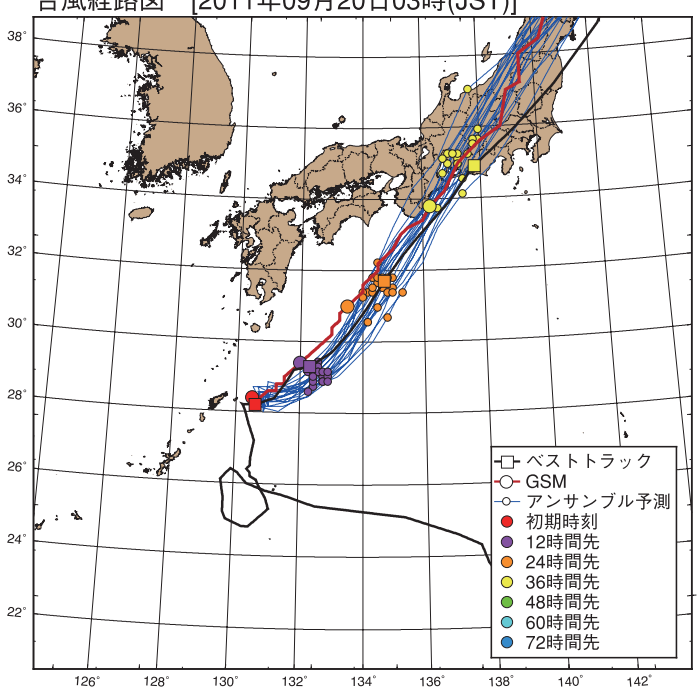

図-15 ベストトラック，GSMおよびアンサンブル予 測の台風進路図（台風 15 号, 予測初期時刻：9 月 20 日 3 時)

Fig. 15 Best-track and forecasted typhoon track by GSM and the ensemble simulation: Typhoon 15; initial time 03 JST 20 Sep. 2011.

台風経路図 [2011年07月18日09時(JST)]

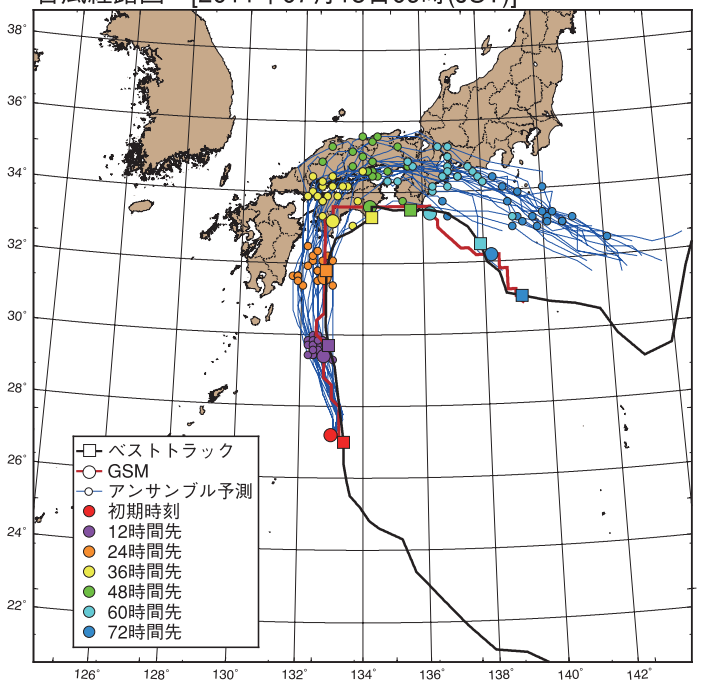

図-16 ベストトラック，GSMおよびアンサンブル予 測の台風進路図（台風6号, 予測初期時刻：7 月 18 日9時)

Fig. 16 Best-track and forecasted typhoon track by GSM and the ensemble simulation: Typhoon 6; initial time 09 JST 18 July 2011.

評価の予測になったと考えられる。

また, 台風 12 号については48時間先以降の予測

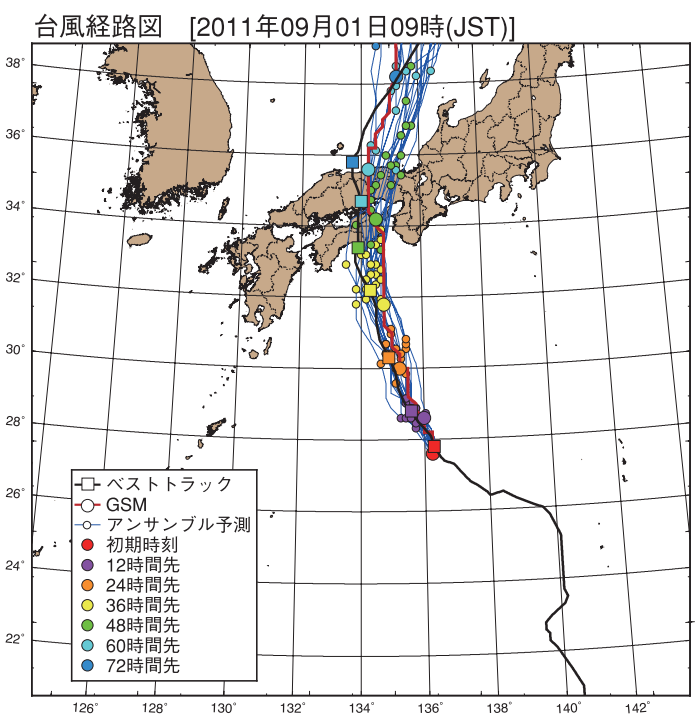

図-17 ベストトラック，GSMおよびアンサンブル予 測の台風進路図（台風12号, 予測初期時刻：9 月 1 日 9 時)

Fig. 17 Best-track and forecasted typhoon track by GSM and the ensemble simulation: Typhoon 12; initial time 09 JST 1 Sep. 2011.

においてアンサンブルで予測された台風進路の精度 が低いだけでなく，特に48時間先以降の予測につい てアンサンブルメンバー間の予測進路のばらつきが 非常に大きいことが図一17よりうかがえる。アンサ ンブルで予測された台風の位置を，台風6号に関す る予測である図ー16および台風 12 号に関する予測 である図ー17の48時間後の予測について調べると， 台風6号ではアンサンブルメンバー間で経度方向に 最大で $280 \mathrm{~km}$ 離れており標準偏差は70 kmであっ た。また緯度方向は最大で $200 \mathrm{~km}$ 離れており, 標準 偏差は50 kmであった。 それに対し台風12号では, アンサンブルメンバー間で経度方向は最大で $190 \mathrm{~km}$ 離れており，標準偏差は50 kmであり台風6号と比 較してやや小さい值となっていた。しかし緯度方向 は最大で $570 \mathrm{~km}$ 離れ, 標準偏差は $140 \mathrm{~km}$ であり台 風6号に関する予測と比較してアンサンブルメン バー間の予測進路のばらつきが非常に大きいことが 分かる。このことから，アンサンブルで予測された 台風進路のばらつきの大きさは, その台風の進路予 測の不確実性 ·予測の困難さを示唆していると考え られる。次にアンサンブル予測の境界条件として用 いられたGSMの予測についてみてみると, 48時間後 や60時間後についてはベストトラックとGSMの予 


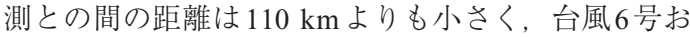
よび台風 15 号の事例と比較して予測誤差がやや小さ いことが分かる。それにも関わらず上で述べたとお り台風 12 号のアンサンブル予測雨量の精度は台風6 号に関する予測よりも著しく低い結果となった。

3つの台風に関する以上の考察から，アンサンブ ル予測雨量の精度は境界条件として用いたGSMの 予測位置の精度のみに依存するわけではなく、アン サンブルで予測された台風進路の精度やアンサンブ ルメンバー間のばらつきの大きさに依存している可 能性が示唆された。今後は, 台風6号についてアン サンブル予測がベストトラックよりも北側に大回り する進路を予測したことや台風 12 号についてアンサ ンブルメンバー間で台風の進路予測が大きくばらつ いたことに代表されるように，アンサンブルメン バーの台風予測進路に着目して精査することが必要 である。

\section{2. ダム管理の実務への適用に向けた課題}

今回の結果から, 現状ではアンサンブル予測雨量 の精度は事例によってばらつきがあり，台風 12 号の ように著しく精度が低い事例も存在する。低い予測 精度のアンサンブル予測雨量に従って操作を行った 結果として本則操作よりも放流量を増加させること や早い夕イミングでただし書き操作に入ってしまう ことは, ダムに要求される所定の洪水調節効果を発 揮できなかったことを意味するため，そのような操 作は避けなければいけない，そのため，台風6号，15 号のような成功する事例が存在する一方で, 台風 12 号のような事例が存在する現状においては本報告で 述べた手法を実務に即適用することは難しい，今後 実務に適用するためには，台風 12 号のような操作を 避けるための工夫が必要と筆者らは考える。その一 案として, リアルタイムでその時点のアンサンブル 予測の精度が高いか低いかを判断し，予測精度が低 いと想定される場合においては下流の危険度を高め てしまう可能性が高いアンサンブル予測に基づく操 作は実施せずに，最適操作ではないものの確実に所 定の洪水調節機能を発揮すべく本則操作を行うと判 断することが考えられる。そのための具体的な考え 方としては，図一17に示された台風12号の事例の ように，アンサンブル予測で計算された台風進路の ばらつきは台風進路予測の不確実性を示唆している と考え，ばらつきが小さい場合は台風進路予測の確 実性が高いと判断しアンサンブル予測に基づく操作
を行い，反対にばらつきが大きい場合は台風進路予 測が不確実であると判断し，アンサンブル予測に基 づく操作ではなく本則操作を行うことが考えられ る、ばらつきは，台風進路に関するアンサンブルメ ンバー間の距離の大きさや標準偏差等を用いて定量 化することが考えられるが，これについては今後の 検討課題である。 または, 海外の気象機関が行って いる台風進路予測も利用して台風進路の予測不確実 性を評価し，不確実性が高い場合は本則操作に基づ く操作, 不確実性が低い場合はアンサンブル予測に 基づく操作を実施することも考えられる，今後はこ れらの案について検討する必要がある。

\section{V、まとめと課題}

2011 年の台風 6, 12, 15 号を対象として GSM84 時間 予測を初期值・境界值としたアンサンブル予測雨量 の計算を行い, ダム洪水調節への適用性について調 ベた。まとめと今後の課題・検討を以下に挙げる

\section{1. まとめ}

- 今回行ったGSM84 時間予測を初期值・境界值と したアンサンブル予測計算の結果，Aダム流域 の流域平均雨量でアンサンブル平均值と実績雨 量と比較した場合, 台風6号, 15 号については 満足な予測精度が得られた一方で, 台風12号で は満足な予測結果が得られなかった。アンサン ブル予測雨量の精度はイベント毎に精度にばら つきが存在し，その精度はアンサンブルで予測 された台風進路の精度や台風進路予測のばらつ きと関係があることが示唆された

・ 今回実施したアンサンブル予測雨量の計算にお いては, 84時間という長い予測先行時間であっ ても台風6号, 15 号については著しい予測精度 の低下は生じなかった。また，MSM33時間予 測と比べて予測先行時間が長いため, ダム洪水 調節においては概ね洪水の始まりから終わりま でを見通すことができるため，非常に有益な情 報になり得ると考えられる。

・ アンサンブル予測で一定の精度が得られた事例 については本報告で示した最適放流量決定手法 を利用することで本則操作以上に効果的な洪水 調節が実施可能であることが示された。 その一 方で, 台風 12 号の事例のように予測精度が低い 場合は本則操作よりも下流の危険度を増加させ 
てしまうため，現時点でダム管理の実務におい て即適用することは難しい。 なお，本手法はア ンサンブル予測雨量から得られる情報を活用す ることでその時点における最適放流量を機械的 に算出することができることがメリットである。

\section{2. 今後の課題・検討}

・本報告は少ない検証事例に基づくものであるの でダム管理の実務への適用に向けてはアンサン ブル予測雨量の精度評価を中心として検証事例 を増やす必要がある。

・ アンサンブル予測に基づいた操作により本則操 作よりも下流の危険度を上げてしまう操作は避 けなければいけないため, ダム管理の実務に適 用するためにはアンサンブル予測に基づく操作 を実施するかしないかをリアルタイムで判断す るための手法を今後考案する必要がある.アン サンブルで予測された台風の進路予測のばらつ きの大きさは, リアルタイムでの操作実施判断 の指標として利用できる可能性がある.

・本報告で示した最適放流量決定手法は, アンサ ンブル予測から得られる情報を基に確率的に最 も起こりうる予測流出に対して最適な調節操作 ( = 洪水調節容量を極力多く使用して下流河川 の流量をできるだけ低減させる.）を行うもの と言える。アンサンブル予測には雨量の上限值 や下限值といった幅に関する情報も含まれてい るため, これらの情報を活用して洪水調節だけ でなく事前放流についても今後検討することが 考えられる.

・ 本報告で示したアンサンブル予測は計算量が膨 大であるため計算に長い時間を要する。このア ンサンブル予測計算手法を実際に運用するため にはアンサンブルメンバー数に関する検討も含 めて計算時間の短縮化についても検討が必要と なる.

\section{引用文献}

Bishop C.H., Etherton B.J., Majumdar S.J. 2001. Adaptive Sampling with the Ensemble Transform Kalman Filter. Part I: Theoritical Aspects. Monthly Weather Review 129: 420-436. Cloke H.L., Pappenberger F. 2009. Ensemble flood forecasting: A review. Journal of Hydrology 375: 613-626.

Duan Q., Sorooshian S., Gupta V. K. 1992. Effective and Efficient Global Optimization for Conceptual Rainfall-Runoff Models. Water Resources Research 28(4): 1015-1031.

永戸久喜 2013. 気象庁のメソ数值予報における開発の現状と計
画. 日本気象学会2013年度春季大会講演予稿集: 423 .

猪股広典・深見和彦 2007. 吉野川流域広域水危険度判断支援シス テムの開発. 河川技術論文集. 第13巻: 433-438.

柏井条介·土屋修一·石神孝之 2008. 気候変動による豪雨時の降 雨量変化予測-GCM20による評価を中心に-. 国土技術政策総 合研究所資料, 第462号; 119 .

気象庁. “予測に伴う誤差とアンサンブル予報”, http://www.jma.go. jp/jma/kishou/know/kisetsu_riyou/method/ensemble.html. (参照:2015/09/07).

国土交通省中国地方整備局八田原ダム管理所 2010. “平成22年7 月14日〜14日出水 (梅雨前線) における八田原ダムの洪水調節効 果について”, 2010/07/15, http://www.cgr.mlit.go.jp/hattabara/ info/masscom/material/220715.pdf. (参照:2015/09/07).

国土交通省東北地方整備局 2011. “台風15号による阿武隈川上流 等の出水速報について”. 2011/09/23, http://www.thr.mlit.go.jp/ fukushima/pressedit/content/201109231140570000.html. (参照:2015/09/07).

三石真也・尾関敏久・角 哲也 2011a. WRFによる降雨予測を活用 した新たな洪水調節手法の適用性検討. 水文・水資源学会誌 24 (2) : 110-120.

三石真也・角 哲也・尾関敏久.矢神卓也 2011b. 降雨予測を活用し たダム洪水調節におけるリスク管理に関する研究. ダム工学2 1 (4) :242-250.

Seko H., Miyoshi T., Shoji Y., Saito K. 2011. Data assimilation experiments of precipitable water vapor using the LETKF system: intense rainfall event over Japan 28 July 2008. Tellus, 63A: 402-414.

鈴木俊朗-寺川 陽 1996. 実時間洪水予測のための分布型流出モ デルの開発. 土木技術資料38 (10): 26-31.

社会資本整備審議会 2008. “水災害分野における地球温暖化に伴 う気候変化への適応策のあり方について”. http://www.mlit.go. jp/river/basic_info/jigyo_keikaku/gaiyou/kikouhendou/index. html. (参照:2015/09/07).

社会資本整備審議会 2015. “水災害分野における気候变動適応策 のあり方について 〜災害リスク情報と危機感を共有し, 減災に 取り組む社会へ〜”. http://www.mlit.go.jp/river/shinngikai_ blog/shaseishin/kasenbunkakai/shouiinkai/kikouhendou/ index.html. (参照:2015/09/07).

鳥居謙一 2012. ダム管理の高度化に向けて. 第48回土木学会水工 学に関する夏期研修会講義集Aコース:A-9-1 - A-9-18

牛山朋來・佐山敬洋·岩見洋一·三好建正 2014. 2011年台風12号, 15号を対象としたアンサンブル降雨流出予測実験. 河川技術論 文集20:455-460.

碓水典久·藤井陽介 2009. データ同化 観測・実験とモデルを融 合するイノベーション, 京都大学学術出版界;28-62.

和田一範・村瀬勝彦・冨澤洋介 2004. 気象予測データの利用可能 性に関する研究. 国土技術政策総合研究所資料, 第210号; 45 .

Wang X., Baker D.M., Snyder C., Hamill T.M. 2008a. A Hybrid ETKF-3DVAR Data Assimilation Scheme for the WRF model. Part I: Observing System Simulation Experiment. Monthly Weather Review 136: 5116-5131.

Wang X., Baker D.M., Snyder C., Hamill T.M. 2008b. A Hybrid ETKF-3DVAR Data Assimilation Scheme for the WRF model. Part II: Real Observation Experiments. Monthly Weather Review 136: 5132-5147.

Wang X. 2011. Application of the WRF Hybrid ETKF-3DVAR Data Assimilation System for Hurricane Track Forecasts. Weather and Forecasting 26: 868-884

吉野 純·飯田潤士・安田孝志 2011. モデルアンサンブル予報によ 
る2010年7月可児豪雨の予測可能性. 水工学論文集55:S475S480.

Yu W., Nakakita E., Yamaguchi K. 2013. Assessment of probabilistic flood forecasting using ensemble nwp rainfall with $30 \mathrm{hr}$ forecast time during typhoon events, Advances in River Engineering 19: 235-240.
（受付：2015年 4 月 22 日，受理：2015年 8 月 6 日）

この論文への討議・コメントを, 2016年 5 月末日 まで受け付けます。

\title{
Application of Ensemble Rainfall Forecast to Dam Flood Control
}

\author{
Hironori INOMATA ${ }^{1)}$ Masaki KAWASAKI ${ }^{1)} \quad$ Yusuke GOTO ${ }^{2)}$ \\ Aritoshi MASUDA ${ }^{2)} \quad$ Kazuhiro ARAKI ${ }^{3)}$ Takayuki ARAKI ${ }^{4}$
}

1) Water Cycle Division, River Department, National Institute for Land and Infrastructure Management (NILIM), Ministry of Land, Infrastructure, Transport and Tourism (MLIT)

(1, Asahi, Tsukuba-shi, Ibaraki, 305-0804, Japan)

2) Flood Management Solutions Section, Disaster Mitigation Solutions Department, Japan Weather Association (3-1-1, Higashi-Ikebukuro, Toshima-ku, Tokyo, 170-6055, Japan)

3) River and Water Resources Division, Osaka Main Office, CTI Engineering Co.,Ltd. (1-6-7, Doshomachi, Chuo-ku, Osaka-shi, Osaka, 541-0045, Japan)

4) Water Management and Research Division, Tokyo Main Office, CTI Engineering Co.,Ltd. (3-21-1, Nihombashi-Hamacho, Chuo-ku, Tokyo, 103-8430, Japan)

Ensemble rainfall forecasting was used for dam flood control. Its applicability was studied. First, an ensemble rainfall forecast with 84-hr lead time was simulated using GSM as a boundary condition. Then optimal dam flood control simulation was conducted based on the simulated ensemble rainfall forecast. Typhoons 6, 12, and 15 in 2011 were the experimental rainfall events. Although the lead time was quite long, the ensemble rainfall forecast results were good for Typhoons 6 and 15. Moreover, results showed that this ensemble rainfall forecast is extremely useful for dam flood control because the lead time is sufficiently long to ascertain the timing of the start and the end of the rainfall in advance of the start of the rain. The dam flood control simulation was conducted based on the ensemble rainfall forecast. Results show that the peak discharge in the downstream was less than that by regular control. However, the ensemble rainfall simulation result of Typhoon 12 was not good. Dam flood control by the ensemble rainfall simulation increased the downstream flood risk. Implementation of ensemble rainfall forecasts for dam flood control requires a method to avoid failure in operations because operations that increase downstream risk are strongly prohibited.

Key words : ensemble forecast, dam flood control 